\title{
Yield and Economics of Maize (Zea mays L.) under Various Resource Constraints
}

\author{
Vasant P. Suryavanshi, Sachin S. Khatal and Rohit Y. Karde* \\ College of Agriculture, Vasantrao Naik Marathwada Krishi Vidyapeeth, \\ Latur-413512, Maharashtra, India \\ *Corresponding author
}

\section{A B S T R A C T}

\section{Keywords}

Economics, Maize, Plant protection, RDF, Resource constraints, Weeding, Zea mays

Article Info

Accepted: 24 October 2020 Available Online: 10 November 2020
A field experiment was conducted during Kharif 2019-20 at Agronomy section, College of Agriculture, Latur. The experiment was laid out in Randomized Block Design. The soil was clay loam in texture, low in available nitrogen $\left(124.6 \mathrm{~kg} \mathrm{ha}^{-1}\right)$, low in phosphorus $\left(17.3 \mathrm{~kg} \mathrm{ha}^{-1}\right)$, high in potash $\left(496.7 \mathrm{~kg} \mathrm{ha}^{-1}\right)$ and alkaline in reaction $\left(7.7 \mathrm{p}^{\mathrm{H}}\right)$. The eight treatments were replicated thrice. The treatments were $\mathrm{T}_{1}:$ Full package of practices, $\mathrm{T}_{2}$ : $\mathrm{T}_{1}-\mathrm{RDF}, \mathrm{T}_{3}: \mathrm{T}_{1}-$ Weeding, $\mathrm{T}_{4}: \mathrm{T}_{1}$ - Plant Protection, $\mathrm{T}_{5}: \mathrm{T}_{1}-(\mathrm{RDF}+$ Weeding $), \mathrm{T}_{6}: \mathrm{T}_{1}-$ $\left(\mathrm{RDF}+\right.$ Plant Protection), $\mathrm{T}_{7}: \mathrm{T}_{1}-($ Weeding + Plant Protection $), \mathrm{T}_{8}: \mathrm{T}_{1}-(\mathrm{RDF}+$ Weeding + Plant Protection). The results clearly indicated that grain yield, stover yield (kg $\mathrm{ha}^{-1}$ ), seed index, harvest index (\%), GMR, NMR (₹ $\mathrm{ha}^{-1}$ ) and B:C ratio were significantly influenced by application of all priority inputs. Treatment $\mathrm{T}_{1}$ Full package of practices (FPP) to Kharif maize recorded highest grain yield, stover yield $\left(\mathrm{kg} \mathrm{ha}^{-1}\right)$, seed index, harvest index (\%), GMR, NMR (₹ $\left.\mathrm{ha}^{-1}\right)$ and $\mathrm{B}: \mathrm{C}$ ratio and was found significantly superior over rest of the all treatments. Full package of practices $\left(\mathrm{T}_{1}\right)$ was recorded higher gross and net monetary returns and $\mathrm{B}: \mathrm{C}$ ratio. The treatment of $\mathrm{T}_{8}$ without any input treatments recorded significantly lowest grain yield, stover yield $\left(\mathrm{kg} \mathrm{ha}^{-1}\right)$, seed index, harvest index (\%), GMR, NMR (₹ $\mathrm{ha}^{-1}$ ) and $\mathrm{B}: \mathrm{C}$ ratio over all priority inputs treatments. Therefore, RDF is suggested to apply on a priority basis followed by weeding and plant protection.

\section{Introduction}

Maize (Zea mays L.) is an annual $\mathrm{C}_{4}$ plant belonging to the grassy family of Poaceae with origin in Central America and regarded as one of the fastest growing cash crop in the world, becoming the largest component of the global coarse grain trade. It is the preferred staple food of 900 million poor people, 120 to 140 million poor farming families and about a third of all malnourished children in the world (Murdia et al., 2016).

Corn is one of the most important cereal crops in the global agricultural economy and it is cultivated all over the world as it has a genetic yield potential higher than any other cereal crop and there is no cereal crop on earth that have enormous potential and therefore it is referred to as the "Queen of Cereals" or 
"Miracle Crop". It is a productive food crop and has the highest potential for accumulating carbohydrates per unit area per day (Murdia et al., 2016). In addition to being an essential human food and animal feed, it provides valuable raw materials for various industries based on agriculture in addition to its common use such as human food grains, bakery products, corn oil, feed and fodder for poultry and livestock (Chaudhary, 1983). In addition, corn starch is also used in textiles, paper and cardboard etc. (Delorite and Ahlgren, 1967). In India, around $35 \%$ of the corn produced in the country is currently used for human consumption, $25 \%$ each for cattle feed and poultry feed and $15 \%$ for food processing and other industries. It has a wide range of uses and the variety of environments in which it is grown cannot be matched by any other culture (Doswell et al., 1996).

Compared to most grains, corn is exposed to fewer biotic and abiotic production restrictions (Joshi et al., 2005). Weeds are the major problem during the rainy season and weed damage to the maize crop may be as high as $50-75 \%$. Most farmers control weeds and do all crop management operations nearly twice.

Among the insect pests, caterpillars, stem borer and termites severely impair plant growth and maize production at all study sites. Rats also severely damage corn cobs in all areas. Weevils and cutworms are found in Bihar; jassids, aphids, moths and white grubs in Madhya Pradesh, grasshoppers and white grubs in Rajasthan and pink borers and termites in Andhra Pradesh and Karnataka. Lepidopteran Fall Armyworm was recently discovered in India, which feeds on more than 80 types of crops, causing damage to economically important grains such as maize. In corn, this pest cause severe leaf feeding damage and direct injury to the ear (FAO, 2017). Disease is one of the most important biotic constraints to reduce crop yield and degrade the quality of the product, which ultimately lowers the market price (Subedi, 2015).

Corn is an important grain crop in India, but it has low productivity. Efforts should therefore be made to increase the yield per hectare of corn. Resource constraints refer to limitations of the cultivation operations and basic agricultural inputs such as RDF application, weed management and protection for plants which are necessary for better plant growth and development and improved greater efficiency and economic benefits. Studying resource constraints helps farmers in rainfed and dryland agriculture as in the case of limited funding, where the process (constraint) is more important in relative to maximum productivity and higher cash return, so that the farmers prioritize that particular operation.

\section{Materials and Methods}

\section{Experimental site}

The field experiment was conducted during kharif season of 2019-20, at Agronomy Section Farm, College of Agriculture, Latur (Maharashtra).

\section{Soil characteristics}

The soil of experimental plot was medium and black in color with good drainage. The topography of experimental field was uniform and fairly leveled. The representative soil samples from 0 to $30 \mathrm{~cm}$ depth were taken from randomly selected plots all over the experimental field before laying out the experiment. A composite soil sample of about half $\mathrm{kg}$ was taken and analyzed for the determination of various physical and chemical properties of soil. The data showed that the soil of experimental plot was clayey 
in texture with chemical composition such as low in available nitrogen (124.6 $\left.\mathrm{kg} \mathrm{ha}^{-1}\right)$, medium in available phosphorous $(17.3 \mathrm{~kg}$ ha ${ }^{1}$ ) and very high in available potassium (496.7 $\left.\mathrm{kg} \mathrm{ha}^{-1}\right)$. The soil was moderately alkaline in reaction having $\mathrm{p}^{\mathrm{H}}(7.7)$.

\section{Experimental details}

The experiment was laid out in a randomized block design with seven treatments and replicated thrice. The treatments were $\mathrm{T}_{1}$ : Full package of practices, $T_{2}$ : $T_{1}-\mathrm{RDF}, \mathrm{T}_{3}: \mathrm{T}_{1}-$ Weeding, $\mathrm{T}_{4}: \mathrm{T}_{1}$ - Plant Protection, $\mathrm{T}_{5:} \mathrm{T}_{1}$ $\left(\mathrm{RDF}+\right.$ Weeding), $\mathrm{T}_{6}: \mathrm{T}_{1}-(\mathrm{RDF}+$ Plant Protection), $\mathrm{T}_{7}: \mathrm{T}_{1}-$ (Weeding + Plant Protection $), \mathrm{T}_{8}: \mathrm{T}_{1}-(\mathrm{RDF}+$ Weeding + Plant Protection).

\section{Seed and seed treatment}

Maize variety Dekalb hybrid (Pinnacle seed Company) was sown at the seed rate of $15 \mathrm{~kg}$ $\mathrm{ha}^{-1}$ at inter row of $60 \mathrm{~cm}$ and plant to plant spacing of $30 \mathrm{~cm}$. Shallow furrows were opened and seeds were sown manually at the depth of $5 \mathrm{~cm}$.

\section{Manures and fertilizers}

As per treatments, half dose of nitrogenous fertilizers and full dose of phosphatic and potassic fertilizers were applied. The next half dose of nitrogen fertilizer was applied in bands as top dressing one month after sowing. The sources of nitrogen, phosphorus and potash were urea, single super phosphate (SSP) and muriate of potash (MOP), respectively.

\section{Weed control}

Two hand weeding first at 20 days and second at 30 days after sowing were under taken to remove the weeds from the experimental plot.

\section{Plant protection measure}

Four spraying were given to protect crop from pest. First spraying was done 16 days after sowing with Azadirachtin@ @ 40ml 10 lit $^{-1}$ water, second was done 23 days after sowing with Proclaim 5gm/10 lit, third was done after 32 days after sowing with Delegate @ 8.5$10 \mathrm{ml} 10 \mathrm{lit}^{-1}$ water and fourth was done after 48 days after sowing with Ampligo @ $5 \mathrm{ml}$ $10 \mathrm{lit}^{-1}$ for American fall army worm.

\section{Yield and economics}

The total weight of fresh green cobs from each net plot treatment wise was recorded after harvest and calculated as cob yield per hectare. The treatment wise weight of green plants after removal of green cobs from each net plot was recorded separately and converted into green fodder yield per hectare.

The cost of cultivation for each treatment was worked out taking in prevailing market price of inputs. Similarly gross returns were calculated based on prevailing market price of the produce. The net returns $\mathrm{ha}^{-1}$ was calculated by deducting the cost of cultivation from the gross returns $\mathrm{ha}^{-1}$ basis.

\section{Results and Discussion}

\section{Grain yield ( $\left.\mathrm{kg} \mathrm{ha}^{-1}\right)$}

Data relating to grain yield $\left(\mathrm{kg} \mathrm{ha} \mathrm{h}^{-1}\right)$ as influenced by different treatments are presented in Table 1. Mean grain yield was $2932 \mathrm{~kg} \mathrm{ha}^{-1}$. With the use of full package of practices $\left(T_{1}\right)$ a significantly higher grain yield $\left(5166 \mathrm{~kg} \mathrm{ha}^{-1}\right)$ was recorded, which was significantly superior to the rest of the treatment. The lowest grain yield (1197 $\mathrm{kg} \mathrm{ha}{ }^{-1}$ ) was recorded with the treatment $\mathrm{T}_{8}$ where RDF, weeding and plant protection was excluded. 


\section{Stover yield $\left(\mathrm{kg} \mathrm{ha}^{-1}\right)$}

Data shown in Table 1 indicated that the mean stover yield of maize was $4594 \mathrm{~kg} \mathrm{ha}^{-1}$. The stover yield per hectare was significantly influenced by different treatments.

The application of full package of practices $\left(T_{1}\right)$ was recorded highest stover yield (7179 $\mathrm{kg} \mathrm{ha}^{-1}$ ) and found significantly superior to the rest of all the treatments. The lowest stover yield $\left(2184 \mathrm{~kg} \mathrm{ha}^{-1}\right)$ was obtained when $\mathrm{RDF}$, weed control and plant protection was not adopted $\left(\mathrm{T}_{8}\right)$.

\section{Biological yield ( $\left.\mathrm{kg} \mathrm{ha}^{-1}\right)$}

Data on biological yield as affected by different treatments are presented in Table 1. The mean biological yield was $7526 \mathrm{~kg} \mathrm{ha}^{-1}$. The biological yield was significantly differed due to various treatments. The application of full package of practices $\left(\mathrm{T}_{1}\right)$ produced significantly higher biological yield (12346 $\mathrm{kg} \mathrm{ha}^{-1}$ ) and was found significantly superior over rest of all the treatments.

The lowest biological yield (3381 $\mathrm{kg} \mathrm{ha}^{-1}$ ) was recorded when RDF, weed control and plant protection was not given $\left(\mathrm{T}_{8}\right)$ and significantly inferior over rest of the treatments.

\section{Harvest index (HI)}

Data on harvest index is indicated in Table 1 and revealed that the mean harvest index of maize crop was $38.37 \%$ and which was influenced due to effect of different treatments.

The application of full package of practices $\left(\mathrm{T}_{1}\right)$ recorded maximum harvest index $(41.85$ $\%$ ), whereas minimum harvest index (35.39 $\%$ ) was recorded with treatment $\mathrm{T}_{8}$.

\section{Economics}

\section{Gross monetary return (₹ ha $\left.{ }^{-1}\right)$}

Data on the gross monetary return (GMR) as influenced by various treatments are presented in Table 2. The mean gross monetary return of maize was recorded as ₹ $61966 \mathrm{ha}^{-1}$. The gross monetary return was influenced significantly due to various treatments. Significantly highest gross monetary return (₹ $107350 \mathrm{ha}^{-1}$ ) was obtained with the application of full package of practices $\left(T_{1}\right)$. This treatment was found significantly superior over rest of all the treatments while treatment $\mathrm{T}_{8}$ (no RDF, weeding and plant protection) gave significantly lowest gross monetary return ₹ $25907 \mathrm{ha}^{-1}$.

\section{Net monetary return $\left(₹ h^{-1}\right)$}

Data relating to net monetary returns of various treatments are presented in Table 2. The mean net monetary return of maize was ₹ $26910 \mathrm{ha}^{-1}$. The net monetary return of maize was significantly influenced due to various treatments and significantly higher net monetary return ( $₹ 60938 \mathrm{ha}^{-1}$ ) was recorded with the application of full package of practices $\left(T_{1}\right)$ as compared with all the treatment. The lowest net monetary return (₹ $2257 \mathrm{ha}^{-1}$ ) was recorded with treatment $\mathrm{T}_{8}$ where RDF, weed management and plant protection was not given.

\section{Benefit: Cost ratio}

Data in respect of B:C ratios as influenced by different treatments are presented in Table 2. The mean benefit: cost ratio was observed as 1.71. The higher B:C ratio (2.31) was observed with the full package of practices $\left(T_{1}\right.$ ), whereas treatment $T_{8}$ ( no RDF, weed control and plant protection) and $\mathrm{T}_{5}$ (no RDF and weed control) was recorded lowest B:C ratio (1.10 and 1.15 respectively). 
Table.1 Mean grain, stover, biological yield $\left(\mathrm{kg} \mathrm{ha}^{-1}\right)$ and harvest index (\%) as influenced by various treatment

\begin{tabular}{|c|c|c|c|c|}
\hline Treatments & $\begin{array}{c}\text { Grain } \\
\text { yield } \\
\left(\mathrm{kg} \mathrm{ha}^{-1}\right)\end{array}$ & $\begin{array}{c}\text { Stover } \\
\text { yield } \\
\left(\mathrm{kg} \mathrm{ha}^{-1}\right)\end{array}$ & $\begin{array}{c}\text { Biological } \\
\text { yield } \\
\left(\mathrm{kg} \mathrm{ha}^{-1}\right)\end{array}$ & $\begin{array}{c}\text { Harvest } \\
\text { index } \\
(\%)\end{array}$ \\
\hline $\mathbf{T}_{\mathbf{1}}$ Full Package & 5166 & 7179 & 12346 & 41.85 \\
\hline $\mathbf{T}_{2:} \mathrm{T}_{1}-\mathrm{RDF}$ & 3191 & 5128 & 8319 & 38.36 \\
\hline $\mathbf{T}_{3:} \mathbf{T}_{1}-$ Weeding & 3514 & 5413 & 8927 & 39.36 \\
\hline $\mathbf{T}_{4}: \mathrm{T}_{1}$ - Plant Protection & 3894 & 5793 & 9687 & 40.20 \\
\hline $\mathbf{T}_{5:} \mathrm{T}_{1}-(\mathrm{RDF}+\mathrm{Weeding})$ & 1804 & 3134 & 4938 & 36.54 \\
\hline $\mathbf{T}_{\mathbf{6 :}} \mathrm{T}_{1}-(\mathrm{RDF}+$ Plant Protection $)$ & 2279 & 3875 & 6154 & 37.04 \\
\hline $\mathbf{T}_{7:} \mathrm{T}_{1}-$ (Weeding + Plant Protection $)$ & 2412 & 4046 & 6458 & 37.35 \\
\hline $\begin{array}{l}\mathbf{T}_{8:} \mathrm{T}_{1}-(\mathrm{RDF}+\text { Weeding }+ \text { Plant } \\
\text { Protection })\end{array}$ & 1197 & 2184 & 3381 & 35.39 \\
\hline $\mathrm{SE}+$ & 178 & 221 & 297 & - \\
\hline C.D. at $5 \%$ & 538 & 667 & 896 & - \\
\hline General Mean & 2932 & 4594 & 7526 & 38.37 \\
\hline
\end{tabular}

Table.2 Mean gross return, cost of cultivation, net return (₹ $\left.\mathrm{ha}^{-1}\right)$ and $\mathrm{B}: \mathrm{C}$ ratio as influenced by various treatments

\begin{tabular}{|c|c|c|c|c|}
\hline Treatments & $\begin{array}{c}\text { Gross } \\
\text { return } \\
\left(₹ \text { ha }^{-1}\right)\end{array}$ & $\begin{array}{c}\text { Cost of } \\
\text { cultivation } \\
\left(₹ \mathrm{ha}^{-1}\right)\end{array}$ & $\begin{array}{c}\text { Net } \\
\text { return } \\
\left(₹ \text { ha }^{-1}\right)\end{array}$ & $\begin{array}{l}\text { B:C } \\
\text { ratio }\end{array}$ \\
\hline $\mathbf{T}_{1:}$ Full Package & 107350 & 46412 & 60938 & 2.31 \\
\hline $\mathbf{T}_{2:} \mathrm{T}_{1}-\mathrm{RDF}$ & 67692 & 39750 & 27942 & 1.70 \\
\hline $\mathbf{T}_{3:} \mathbf{T}_{1}-$ Weeding & 74074 & 40512 & 33562 & 1.83 \\
\hline $\mathbf{T}_{4}: T_{1}$ - Plant Protection & 81671 & 36412 & 45259 & 2.24 \\
\hline $\mathbf{T}_{5}: \mathrm{T}_{1}-(\mathrm{RDF}+$ Weeding $)$ & 38746 & 33650 & 5096 & 1.15 \\
\hline $\mathbf{T}_{\mathbf{6}} \mathrm{T}_{1}-(\mathrm{RDF}+$ Plant Protection $)$ & 48775 & 29650 & 19125 & 1.65 \\
\hline $\mathbf{T}_{7:} \mathbf{T}_{1}-$ (Weeding + Plant Protection) & 51510 & 30412 & 21098 & 1.69 \\
\hline $\begin{array}{l}\mathbf{T}_{\mathbf{8}} \mathrm{T}_{1}-(\mathrm{RDF}+\text { Weeding }+ \text { Plant } \\
\text { Protection })\end{array}$ & 25907 & 23650 & 2257 & 1.10 \\
\hline $\mathrm{SE}+$ & 3280 & - & 3280 & - \\
\hline C.D. at $5 \%$ & 9902 & - & 9902 & - \\
\hline General Mean & 61966 & 35031 & 26910 & 1.71 \\
\hline
\end{tabular}

The treatment $T_{1}$ i.e. full package of practices where application of RDF, weed free condition and plant protection was done reported maximum grain yield $\left(5166 \mathrm{~kg} \mathrm{ha}^{-1}\right)$, stover yield (7179 $\left.\mathrm{kg} \mathrm{ha}^{-1}\right)$, biological yield $\left(12346 \mathrm{~kg} \mathrm{ha}^{-1}\right)$ and harvest index $(41.85 \%)$. This was due to maximum growth and development, resulted to higher grain, stover, biological yield and harvest index. Due to high number of weeds and pest infestation with missing of RDF, the treatment $\mathrm{T}_{8}$ produced lowest grain yield (1197 kg ha-1), stover yield (2184 $\left.\mathrm{kg} \mathrm{ha}^{-1}\right)$, biological yield (3381 kg ha-1) and harvest index $(35.39 \%)$. 
Similar results have been reported by Kausalye et al., (2017), Chongtham et al., (2017), Rao et al., (2009), Priya et al., (2014), Barad et al., (2016), Daoudi and Singh (2017).

The treatment $T_{1}$ with application of full package of practices (FPP) where RDF application, complete weed management and plant protection was done, reported maximum gross monetary returns ( $₹ 107350 \mathrm{ha}^{-1}$ ) due to increment in dry matter and maximum grain yield which was followed by the treatment $\mathrm{T}_{4}$ (₹ $81671 \mathrm{ha}^{-1}$ ) where plant protection was excluded and lowest gross monetary returns (₹ $25907 \mathrm{ha}^{-1}$ ) due to high weed and pest infestation and missing of RDF. The treatment $T_{1}$ with application of FPP where RDF application, complete weed management and plant protection was done, reported maximum net monetary returns ( $₹ 60938$ ha $\left.{ }^{1}\right)$ due to increment in gross monetary returns which was followed by the treatment $\mathrm{T}_{4}$ (₹ $45259 \mathrm{ha}^{-1}$ ) where plant protection was excluded and lowest net monetary returns ( $₹$ $2257 \mathrm{ha}^{-1}$ ) due to high weed and pest infestation and missing of RDF and likewise highest benefit: cost ratio was reported with full package of practices $\left(\mathrm{T}_{1}\right)$. Similar results have been reported by Kausalye et al., (2017), Chongtham et al., (2017), Barad et al., (2016), Rao et al., (2009) and Priya et al., (2014).

In conclusion the application of full package of practices $\left(\mathrm{T}_{1}\right)$ recorded higher growth and yield attributes (5166 $\left.\mathrm{kg} \mathrm{ha}^{-1}\right)$ in maize production while missing of RDF, weeding and plant protection as a individual or in combination caused for reduction in yield and notified as a major resource constraints in maize production. The highest gross monetary returns and net monetary returns and $\mathrm{B}: \mathrm{C}$ ratio was recorded with application of full package of practices $\left(T_{1}\right)$, while the lowest gross and net monetary returns and $\mathrm{B}: \mathrm{C}$ ratio was recorded with the treatment $T_{8}$ where $\mathrm{RDF}$, weed management and plant protection were missing from full package of practices. Therefore, RDF is suggested to apply on a priority basis followed by weeding and plant protection.

\section{Acknowledgement}

The authors gratefully acknowledge the College of Agriculture, VNMKV, Latur, Maharashtra, who permitted to carry out this research work by using all the facilities available.

\section{References}

Barad, B., Mathukia, R. K., Gohil, B. S. And Chhodavadia, S. K. (2016). Integrated weed management in rabi popcorn (Zea mays var. everta). Journal of Crop and Weed. 12(1):150-153.

Chaudhury, A. R. (1983). Maize in Pakistan. Punjab Agriculture Research Coordination Board, University of Agriculture, Faisalabad, Pakistan.

Chongtham, S.K., Jain, S.K. and Patel, P.R. (2015). Effect of production resource constraints on yield and economics of kharif sorghum in the Northern Gujarat region. Journal of Pharmacognosy and Phytochemistry. 7(3): 3221-3223.

Daoudi, M. and Singh, R. (2017). Effect of nitrogen and sulphur on growth and yield of hybrid maize (Zea mays L.). International Journal of Current Microbiology and Applied Sciences. 6(6): 1930-1935.

Delorite, R. J. and Ahlgren, H. L. (1967). Crop Production. 3rd edition, Prentice Hall, Inc. Englewood Cliffs, New Jersy.: 34-35.

Doswell, C. D., Paliwal, R. L. and Cantrell, R. P. (1996). Maize in the third world. Boulder, Co, USA, Westview Press.

Joshi, P.K; Singh, N.P; Singh, N.N. (2005). 
Maize in India: Production system, constraints and research priorities. International maize and wheat improvement centre, Maxico.: Pp. 18-19.

Kausalye, S.P., Aundhekar, R.L., Solunke, S.S. and Kalpande, H.V. (2017). Optimization of production factors in rabi grain sorghum under resource constraints. Agriculture Update. 12: 1201-1203.

Murdia, L. K., Wadhwani, R., Wadhawan, N., Bajpai, P. and Shekhawat, S. (2016). Maize utilization in India: an overview. American Journal of Food and Nutrition. 4(6): 169-176.
Priya, S., Kaushik, M. K, Sharma, S. K. and Kumawat, P. (2014). Impact of integrated nutrient management on growth and productivity of hybrid maize (Zea mays L.). Annals of Biology. 30(1): 106-108.

Rao, A. S., Ratnam, M. and Reddy, T. Y. (2009). Weed management in zero-till sown maize. Indian Journal of Weed Science. 41(1-2): 46-49.

Subedi, (2015). A review on important maize diseases and their management in Nepal. Journal of Maize Research and Development. 1(1): 28-52.

How to cite this article:

Vasant P. Suryavanshi, Sachin S. Khatal and Rohit Y. Karde. 2020. Yield and Economics of Maize (Zea mays L.) under Various Resource Constraints. Int.J.Curr.Microbiol.App.Sci. 9(11): 3618-3624. doi: https://doi.org/10.20546/ijcmas.2020.911.433 